The Effects of Temperature on Germination of Eeven Festuca Cultivars

Antonio J. Palazzo and Gurdarshan S. Brar 
Abstract: Many studies have shown that water potential at planting affects the germination rate and final germination of Festuca cultivars. Limited information is available about the extent of variability in temperature-dependence of germination among different Festuca cultivars. Our objective was to study germination at five temperatures for a wide range of Festuca cultivars. Festuca seeds were screened for germination during 28 days in polyethylene growth pouches held at constant temperatures of $10,15,20$, 25 , or $30^{\circ} \mathrm{C}$. The germination percentage significantly $(p<0.05)$ increased as the temperature increased from 10 to $15^{\circ} \mathrm{C}$, when averaged across the cultivars, and decreased thereafter. The cultivar "Clemfine" tall fescue (Festuca arundinacea Schreb.) had the greatest germination percentage, and "Arctared" red fescue (Festuca rubra L.) had the least when averaged across the five temperatures. Conversely, the average time to germination $\left(A_{\mathrm{tg}}\right)$ was greatest at $10^{\circ} \mathrm{C}$ and least at $30^{\circ} \mathrm{C}$. Reaching a germination level of $80 \%$ or more of the seeds required 14 days at $10^{\circ} \mathrm{C}, 9 \mathrm{~d}$ at $15^{\circ} \mathrm{C}, 8 \mathrm{~d}$ at $20^{\circ} \mathrm{C}$, and $7 \mathrm{~d}$ at 25 or $30^{\circ} \mathrm{C}$. Base temperatures required for germination of Festuca species were $3.2^{\circ} \mathrm{C}$ for rapid germinators, 3.6 to $6^{\circ} \mathrm{C}$ for medium germinators, and 4 to $6^{\circ} \mathrm{C}$ for poor germinators. Heat units (growing degree-days $>10^{\circ} \mathrm{C}$ ) calculated for the rapid germinators were $129^{\circ} \mathrm{C}-\mathrm{d}$, 120 to $140^{\circ} \mathrm{C}-\mathrm{d}$ for medium germinators, and 135 to $191^{\circ} \mathrm{C}-\mathrm{d}$ for the poor germinators. Germination decreased as heat units were increased. The $A_{\mathrm{tg}}$ and heat unit regressions explained $91 \%$ and $66 \%$ of the variations in germination, respectively. The optimum temperature for germination of Festuca cultivars was $15^{\circ} \mathrm{C}$. Seeding time for some Festuca cultivars could be varied based on expected seed zone temperatures for particular locations. Results of this study should be interpreted with caution, but they suggest that selection for rapid growth rate among materials of favored phenological patterns may lead to improved establishment of faster species on poorly managed sandy soils in cold climates. Rapidity and total germination are the most obvious factors distinguishing Festuca cultivars. This study demonstrates the variability in cultivar germination in response to temperature.

How to get copies of CRREL technical publications:

Department of Defense personnel and contractors may order reports through the Defense Technical Information Center: DTIC-BR SUITE 0944

8725 J OHN J KINGMAN RD

FT BELVOIR VA 22060-6218

Telephone 18002253842

E-mail help@dtic.mil msorders@dtic.mil

WWW http://www.dtic.dla.mil/

All others may order reports through the National Technical Information Service:

NTIS

5285 PORT ROYAL RD

SPRINGFIELD VA 22161

Telephone 17034874650

17034874639 (TDD for the hearing-impaired)

E-mail orders@ntis.fedworld.gov

WWW http://www.fedworld.gov/ntis/ntishome.html

A complete list of all CRREL technical publications is available from:

USACRREL (CECRL-LP)

72 LYME RD

HANOVER NH 03755-1290

Telephone 16036464338

E-mail_techpubs@crrel.usace.army.mil

For information on all aspects of the Cold Regions Research and Engineering Laboratory, visit our World Wide Web site: http://www.crrel.usace.army.mil 


\section{Special Report 97-19}

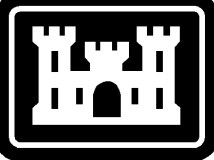

US Army Corps

of Engineers $\odot$

Cold Regions Research \& Engineering Laboratory

\section{The Effec ts of Temperature on Germination of Eeven Festuca Cultivars}

Antonio J . Palazzo and Gurdarshan S. Brar 


\section{PREFACE}

This report was prepared by Antonio J. Palazzo, Research Agronomist, and Gurdarshan S. Brar, Research Physical Scientist, Geochemical Sciences Division, Research and Engineering Directorate, U.S. Army Cold Regions Research and Engineering Laboratory (CRREL), Hanover, New Hampshire.

Funding for this research was supported by project BT-25, work unit BT25-ECB09, entitled Genetic characterization of native plants in cold regions.

Technical review of this report was provided by Dr. Richard Hall, University of Rhode Island; Dr. Ray Taylorson, U.S. Department of Agriculture; and Dr. Charles Racine, CRREL. The authors also thank Timothy Cary for technical support.

The contents of this report are not to be used for advertising or promotional purposes. Citation of brand names does not constitute an official endorsement or approval of the use of such commercial products. 


\title{
The Effects of Temperature on Germination of Eleven Festuca Cultivars
}

\author{
ANTONIO J. PALAZZO AND GURDARSHAN S. BRAR
}

\section{INTRODUCTION}

Once established, hard fescues (Festuca sp.) can survive for many years on military training lands consisting of sandy soils (Palazzo 1994). Major constraints of Festuca establishment are lack of sufficient water in the seed zone, variation in seed zone temperature at planting, and harsh environmental conditions. The period between planting and seedling emergence comprises two distinct temperature-dependent phases: seed germination and preemergence seedling growth (Wheeler and Ellis 1991). Selecting Festuca cultivars for rapid and uniform germination under a wide range of temperatures would seem to be important for early seedling establishment. The cultivars that germinate quickly might be capable of rapidly developing a root system that would move ahead of the drying soil front.

A broad classification of grasses based on optimum temperature coincides with their separation into photosynthetic pathway types: coolseason grasses represent the $\mathrm{C} 3$ pathway, and warm-season grasses use the $\mathrm{C} 4$ photosynthetic pathway (Gould and Shaw 1983). Compared with C3-type plants, C4 species are more resistant to drought (Doliner and Joliffe 1979); however, it is unclear if this analogy extends to the germination and seedling stages. Total germination and germination rates of cool-season and warm-season grasses were significantly influenced by the interaction of temperature and water stresses (Qi and Redmann 1993). High and low temperature extremes increased the sensitivity of germination rate to moisture stress and decreased the germination percentage.

The importance of germination rate in the establishment of annual grasses has been reported in the literature (Derwyn et al. 1966, Smith 1968). The germination rate, defined as the reciprocal of the time taken for half the population to germinate, usually increases linearly with temperature, at least within a well-defined range (Hegarty 1973, Bierhuizen and Wagenvoort 1974, Thompson and Fox 1976).

Selecting Festuca cultivars for rapid and uniform germination under a wide range of temperatures is important for early seedling establishment in the field (Brar and Stewart 1994). Temperature affects germination of grass seeds, with varying responses among species (McWilliam et al. 1970). Slow germination and low seedling vigor limit the establishment of perennial warm-season forage grasses, and temperature is a major environmental factor influencing both processes (Hsu et al. 1985)

Little information is available about environmental influences on germination and the extent of variability in germination at various temperatures for different Festuca cultivars. Therefore, our objective was to study the effect of five temperatures on the germination percentage for a wide range of Festuca cultivars.

\section{MATERIALS AND METHODS}

Festuca germination experiments were conducted in a growth chamber at the U.S. Army Corps of Engineers Cold Regions Research and Engineering Laboratory in Hanover, New Hampshire. Eleven Festuca cultivars (Table 1) were evaluated for germination under various temperatures by a growth pouch technique (Brar et al. 1991). Festuca seeds were obtained from a 
Table 1. Festuca cultivars tested for germination at various temperatures.

\begin{tabular}{|c|c|c|}
\hline Cultivars & Scientific name & Common name \\
\hline $\begin{array}{l}\text { Jamestown, } \\
\text { Victory }\end{array}$ & $\begin{array}{l}\text { Festuca rubra var. } \\
\text { commutata Gaud. }\end{array}$ & Chewings fescue (CF) \\
\hline $\begin{array}{l}\text { Cindy, } \\
\text { Dawson }\end{array}$ & Festuca rubra L. & Creeping red fescue (CRF) \\
\hline $\begin{array}{l}\text { Spartan, } \\
\text { Reliant }\end{array}$ & $\begin{array}{l}\text { Festuca ovina var. } \\
\text { duriuscula (L.) Koch. }\end{array}$ & Hard fescue (HF) \\
\hline $\begin{array}{l}\text { Arctared, } \\
\text { Jasper }\end{array}$ & Festuca rubra L. & Red fescue (RF) \\
\hline Azay & Festuca ovina L. & Sheeps fescue (SF) \\
\hline $\begin{array}{l}\text { Clemfine, } \\
\text { Tribute }\end{array}$ & $\begin{array}{l}\text { Festuca arundinacea } \\
\text { Schreb. }\end{array}$ & Tall fescue (TF) \\
\hline
\end{tabular}

commercial source in New Jersey. Seeds (50) of each cultivar were selected at random and placed in growth pouches. The growth pouches were placed in the germination chamber for six weeks at constant temperatures of 10, 15, 20, 25, or $30^{\circ} \mathrm{C}$ and $75 \%$ relative humidity. Germination counts were recorded daily. Seed germination was determined by radicle protrusion through the seed coat, in accordance with the Association of Official Seed Analysts (AOSA 1970) definition of seed germination.

The germination percentages at 28 days after imbibing were calculated from the total number of seeds germinated at each temperature divided by the total number of seeds used for each cultivar. The weighted mean germination time (Heydecker 1966, Brar and Stewart 1994) or average time to germination ( $A_{\mathrm{tg}}$ in days) was calculated as

$$
A_{\mathrm{tg}}=\Sigma\left(\frac{n \times d}{N}\right)
$$

where $n$ is the number of seedlings germinated on day $d$, and $N$ is the total number of seedlings germinated.

A linear regression model proposed by Angus et al. (1981) was used to estimate the threshold temperature for germination:

$$
A_{\mathrm{tg}}{ }^{-1}=b_{0}+b_{1} T
$$

where $T$ is temperature, and $b_{0}$ and $b_{1}$ are the regression constants. Threshold temperature $\left(T_{\mathrm{b}}\right)$ was estimated as

$$
T_{\mathrm{b}}=\frac{b_{0}}{b_{1}} .
$$

The heat units (HU) (growing days $>10^{\circ} \mathrm{C}$ ) were calculated as

$$
\mathrm{HU}=\left(T-T_{\mathrm{b}}\right) A_{\mathrm{tg}} .
$$

The experimental design was considered as a series of experiments repeated four times over temperature with replications nested within temperature as described by Kempthorne (1952). Within each temperature treatment (germination chamber), the design was a randomized complete block. Separate analyses of variance were structured for germination and average time to germination.

\section{RESULTS AND DISCUSSION}

A pooled analysis of variance indicated that cultivar and temperature treatments had a significant effect on the mean germination and average time to germination of Festuca sp. (Table $2)$. The cultivar $\times$ temperature interactions were also significant $(p<0.001)$ for germination and $A_{\mathrm{tg}}$. This study supports the findings of other workers for forage legumes (Brar et al. 1991), sorghum (Brar and Stewart 1994), and warmseason forage grasses (Hsu et al. 1985).

Table 2. Analysis of variance for laboratory germination and average time to germination $\left(A_{\mathrm{tg}}\right)$ of 11 Festuca cultivars.

\begin{tabular}{lrcc}
\multicolumn{1}{c}{$\begin{array}{c}\text { Source of } \\
\text { variance }\end{array}$} & \multicolumn{3}{c}{ Mean squares } \\
\cline { 2 - 4 } Cultivars $(C)$ & 10 & Germination & $\mathrm{A}_{t g}$ \\
Temperature $(T)$ & 4 & $10477^{*}$ & $88^{*}$ \\
$C \times T$ & 40 & $564^{*}$ & $610^{*}$ \\
Error & 165 & 39 & $8^{*}$ \\
\hline
\end{tabular}

* Significant at $p=0.001$ probability level.

Germination percentage averaged across all cultivars significantly $(p<0.05)$ increased as temperature increased, from $71 \%$ at $10^{\circ} \mathrm{C}$ to $80 \%$ at $15^{\circ} \mathrm{C}$ (Table 3). Germination percentage declined above $15^{\circ} \mathrm{C}$ and remained nearly constant as the temperature increased to $30^{\circ} \mathrm{C}$. Cultivars were grouped into three categories based on mean germination performance across temperature treatments: rapid, with germination above $90 \%$; moderate, with germination between $80 \%$ and $90 \%$; and slow, where germination was less than 80\% (Brar and Stewart 1994). Among the cultivars tested across all temperatures, one was rapid, six were moderate, and four were slow 
Table 3. Mean final germination percentage of Festuca cultivars as influenced by temperature at 28 days.

\begin{tabular}{lcccccc} 
& \multicolumn{7}{c}{ Germination (\%) } \\
Cultivar & $10^{\circ} \mathrm{C}$ & $15^{\circ} \mathrm{C}$ & $20^{\circ} \mathrm{C}$ & $25^{\circ} \mathrm{C}$ & $30^{\circ} \mathrm{C}$ & Mean \\
\hline Jasper & 89 & 93 & 87 & 93 & 86 & 89 \\
Clemfine & 94 & 94 & 88 & 89 & 96 & 93 \\
Jamestown & 94 & 92 & 83 & 88 & 77 & 86 \\
Reliant & 78 & 87 & 92 & 87 & 95 & 88 \\
Azay & 57 & 97 & 87 & 87 & 93 & 84 \\
Spartan & 79 & 88 & 77 & 83 & 72 & 80 \\
Tribute & 64 & 91 & 84 & 84 & 90 & 82 \\
\hline
\end{tabular}

\begin{tabular}{lcccccc} 
& \multicolumn{7}{c}{ Germination (\%) } \\
Cultivar & $10^{\circ} \mathrm{C}$ & $15^{\circ} \mathrm{C}$ & $20^{\circ} \mathrm{C}$ & $25^{\circ} \mathrm{C}$ & $30^{\circ} \mathrm{C}$ & Mean \\
\hline Victory & 81 & 66 & 69 & 75 & 76 & 73 \\
Cindy & 92 & 92 & 55 & 43 & 27 & 60 \\
Dawson & 57 & 66 & 74 & 72 & 70 & 68 \\
Arctared & 0 & 15 & 14 & 17 & 14 & 12 \\
LSD $(0.05)$ & 11 & 7 & 11 & 11 & 8 & 4 \\
Mean & 71 & 80 & 73 & 74 & 72 & \\
LSD $(0.05)=3$ & & & & & & \\
\hline
\end{tabular}

* Least-square differences at $p<0.05$ according to Student-Newman-Keuls test.

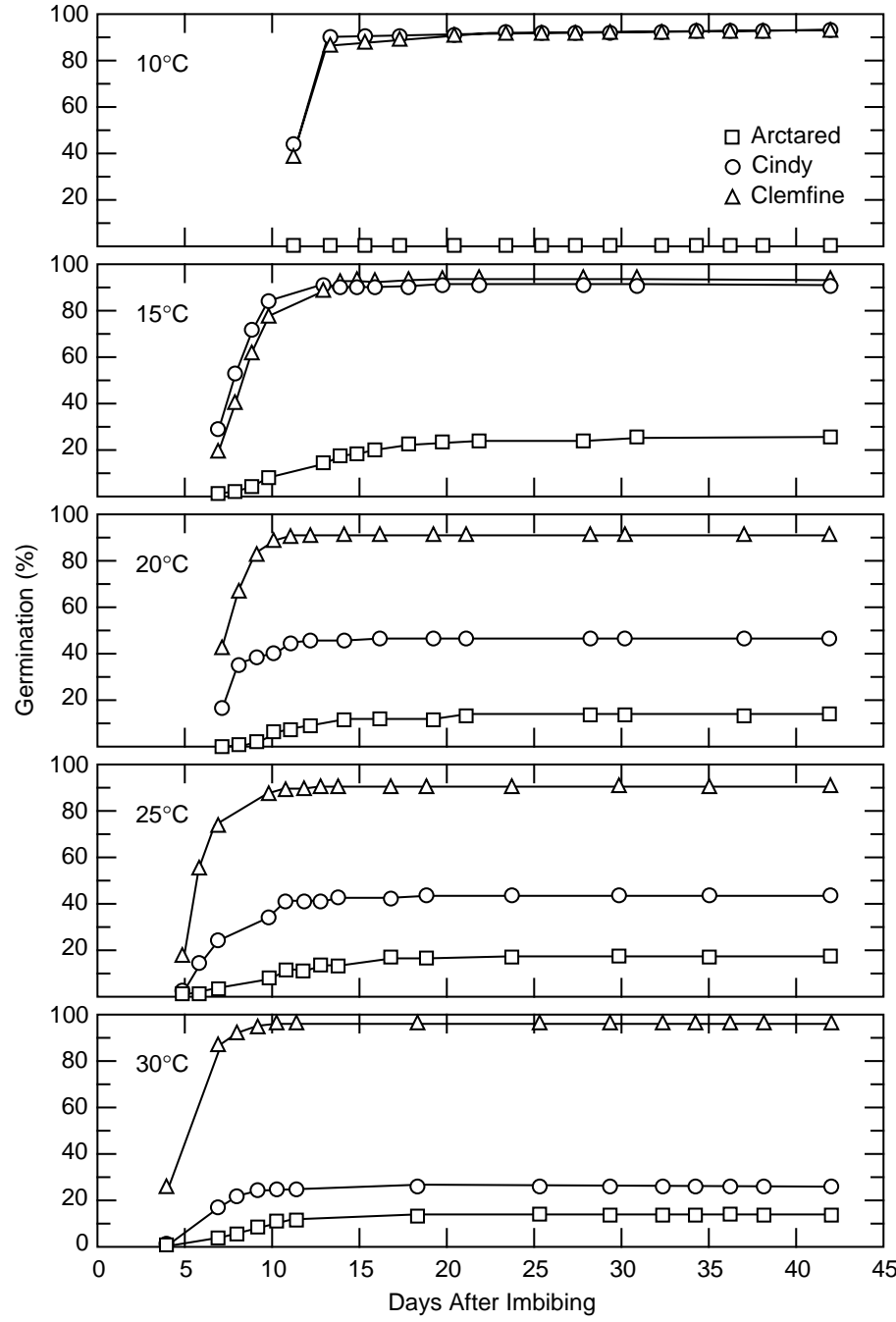

Figure 1. Germination trends for Festuca cultivars as influenced by temperature and time after imbibing.

germinators (Table 3). Clemfine TF had the greatest germination percentage, followed by Jasper RF. The lowest germination percentage was recorded for Arctared RF.

Cultivars that germinate over a relatively wide range of temperatures may be easier to establish in the field than those with a highly specific temperature requirement. Clemfine TF was most vigorous in germination among all the cultivars evaluated because it exhibited the highest germination percentage over a broad range of temperatures. Brar and Palazzo (1995a) reported that Clemfine TF had more rapid root development, grew faster, and transpired more water than Reliant HF. Cultivars Cindy CRF and Victory CF are temperature-specific and performed well at lower temperatures. The cultivars Reliant HF, Azay SF, and Tribute TF were poor germinators at $10^{\circ} \mathrm{C}$ but performed better between $15^{\circ}$ and $30^{\circ} \mathrm{C}$.

Germination time response curves for Arctared RF, Cindy CRF, and Clemfine TF at all the temperatures studied revealed the magnitude of interactions between cultivars and indicated that temperature strongly influenced germination (Fig. 1). At $10^{\circ} \mathrm{C}$, Clemfine TF and Cindy CRF had their greatest germination percentage within 11 to 13 days. However, Arctared did not germinate at $10^{\circ} \mathrm{C}$. At $15^{\circ} \mathrm{C}$, again Clemfine and Cindy reached $>80 \%$ germination at 10 $\mathrm{d}$, while at the same time Arctared had $9 \%$ germination. Similarly, Clemfine exceeded $80 \%$ germination by $9 \mathrm{~d}$ at $20^{\circ} \mathrm{C}, 7 \mathrm{~d}$ at $25^{\circ} \mathrm{C}$, and $6 \mathrm{~d}$ at $30^{\circ} \mathrm{C}$. Conversely, Cindy and Arctared failed to reach even $60 \%$ germination at higher temperatures. In regions where lower temperatures exist at planting, rapidly germinating cultivars such as Clemfine $T F$, Jamestown $C F$, and Jasper RF may be best (Table 3). In addition, an early high germination rate may allow rapid establishment on poorer sandy soils where the 
Table 4. Average time to germination ( $A_{\mathrm{tg}}$ in days) of Festuca cultivars as influenced by temperature.

\begin{tabular}{lrrrrrr} 
& \multicolumn{6}{c}{$A_{\mathrm{tg}}$} \\
\cline { 2 - 7 } Cultivar & $10^{\circ} \mathrm{C}$ & $15^{\circ} \mathrm{C}$ & $20^{\circ} \mathrm{C}$ & $25^{\circ} \mathrm{C}$ & $30^{\circ} \mathrm{C}$ & Mean \\
\hline Jasper & 13.4 & 9.2 & 7.6 & 6.4 & 6.8 & 8.7 \\
Clemfine & 12.5 & 9.3 & 8.0 & 6.8 & 6.3 & 8.6 \\
Jamestown & 13.3 & 8.6 & 8.9 & 6.8 & 8.6 & 9.0 \\
Reliant & 13.5 & 8.6 & 8.5 & 6.5 & 6.8 & 8.8 \\
Azay & 14.8 & 10.0 & 7.9 & 7.4 & 7.3 & 9.5 \\
Spartan & 15.5 & 8.9 & 8.2 & 6.3 & 7.2 & 9.3 \\
Tribute & 14.1 & 9.8 & 8.0 & 6.9 & 6.6 & 9.1 \\
Victory & 14.6 & 9.9 & 8.9 & 8.5 & 7.2 & 9.8 \\
Cindy & 12.4 & 9.0 & 8.5 & 8.2 & 8.6 & 9.3 \\
Dawson & 14.4 & 10.8 & 8.5 & 8.6 & 7.5 & 9.9 \\
Arctared & 25.0 & 14.2 & 12.1 & 11.7 & 10.5 & 14.7 \\
LSD $(0.05)$ & 1.1 & 1.3 & 1.4 & 1.1 & 1.0 & 0.5 \\
Mean & 14.9 & 9.9 & 8.6 & 7.6 & 7.5 & \\
LSD (0.05) & & & & & &
\end{tabular}

$\underline{\operatorname{LSD}}(0.05)=0.3$

* Least-square differences at $<0.05$ according to StudentNewman-Keuls test. water content in the upper soil surface is only available for a short time. Brar and Palazzo (1995b) emphasized that screening of turfgrass for rapid root development is important for both quicker establishment and long-term persistence for disturbed soils and adverse climatic conditions.

Average time to germination decreased as temperature increased from 10 to $15^{\circ} \mathrm{C}$ (Table 4 ). The mean $A_{\text {tg }}$ was greatest at $10^{\circ} \mathrm{C}$ and lowest at $30^{\circ} \mathrm{C}$. Clemfine and Jasper were among the cultivars with lowest $A_{\text {tg }}$ at each temperature. The poor germinator (Arctared RF) had a greater $A_{\text {tg }}$ than the other 10 cultivars. For $80 \%$ or more of the seeds to germinate required an $A_{\mathrm{tg}}$ of $14 \mathrm{~d}$ at $10^{\circ} \mathrm{C}$, $9 \mathrm{~d}$ at $15^{\circ} \mathrm{C}, 8 \mathrm{~d}$ at $20^{\circ} \mathrm{C}$, and $7 \mathrm{~d}$ at 25 or $30^{\circ} \mathrm{C}$.

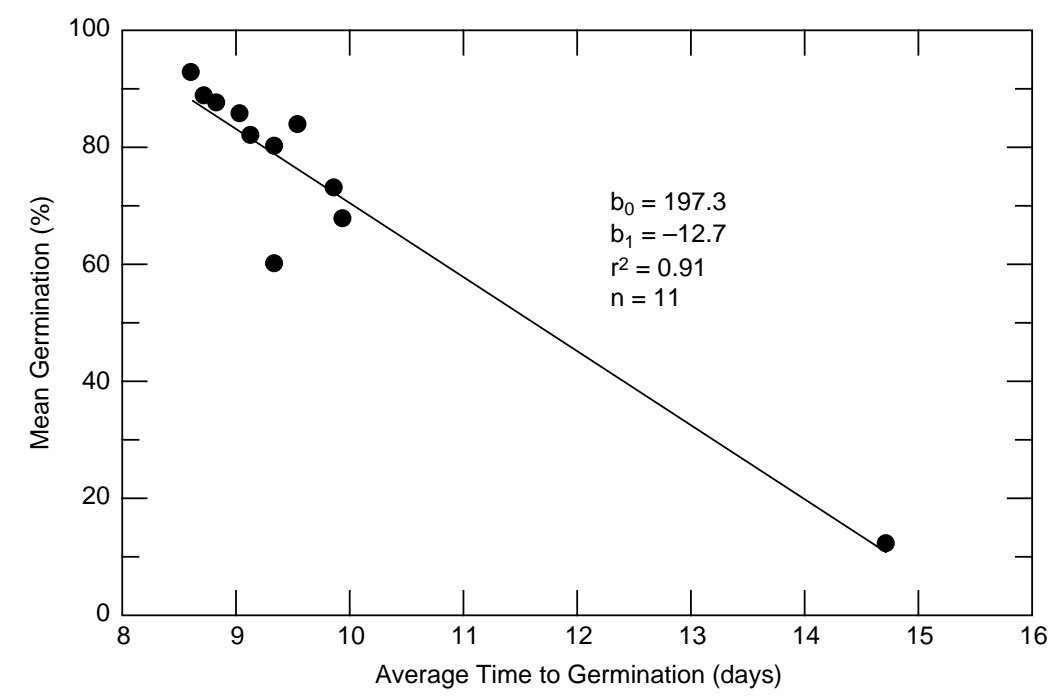

Figure 2. Relationship of mean germination and average time to germination.

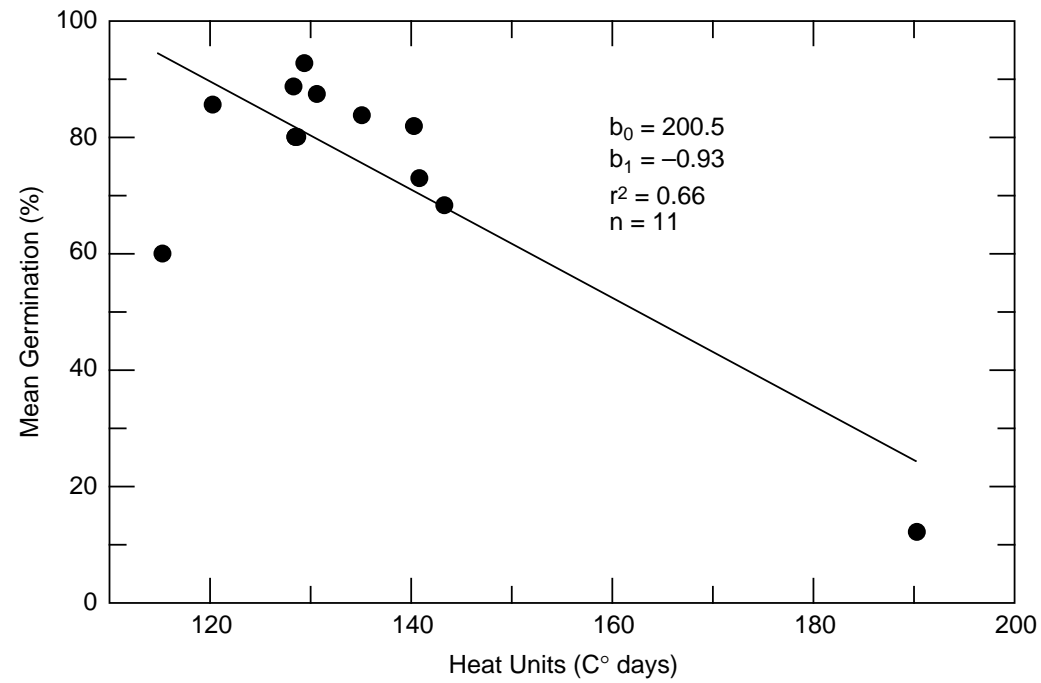

Figure 3. Relationship of mean germination and heat units. 
Base temperatures required for germination of Festuca species were $3.2^{\circ} \mathrm{C}$ for rapid germinators, 3.6 to $6^{\circ} \mathrm{C}$ for medium germinators, and 4 to $6^{\circ} \mathrm{C}$ for poor germinators. Heat units (HU) (growing degree-days $>10^{\circ} \mathrm{C}$ ) calculated for the rapid germinator were $129^{\circ} \mathrm{C}-\mathrm{d}, 120$ to $140^{\circ} \mathrm{C}-\mathrm{d}$ for medium germinators, and 135 to $191^{\circ} \mathrm{C}-\mathrm{d}$ for the poor germinators. Radford and Henzell (1990) reported that differences among sorghum genotypes for germination were due to differences in base temperature. Furthermore, they speculated that any genotype with a high base temperature might have insufficient time to complete elongation of radiate protrusion through the seed coat and subsequently fail to germinate.

The mean germination of Festuca cultivars was significantly $(p<0.05)$ regressed with mean $A_{\mathrm{tg}}$ (Fig. 2) and heat units (Fig. 3). Germination decreased as $A_{\mathrm{tg}}$ and HU increased. The $A_{\mathrm{tg}}$ and HU regressions explained $91 \%$ and $66 \%$ of the variation in germination, respectively.

Cultivars that germinated rapidly had lower HU and $A_{\text {tg }}$ values, so they have the chance to establish in the field earlier than medium and slow germinators (Brar and Stewart 1994).

Rapid and total germination are the most obvious factors distinguishing the cultivars used in this study. The two TFs (Clemfine and Tribute) as a group had a greater total and rate of germination than the other five species. Palazzo and Brar (1997) screened Festuca cultivars for rapid root development and reported that Clemfine TF had the deepest root system and greatest cumulative root elongation rates among the 12 cultivars used in the test. The rate of germination increased linearly with temperature from a base temperature to a sharply defined optimum temperature, beyond which the rate decreased linearly with temperature, reaching zero at the maximum temperature (Garcia-Huidobro et al. 1982).

In summary, we examined the effects of temperature on germination, average time to germination, threshold temperature, and heat units of Festuca cultivars to assess the genetic basis for their variability and the implications for selection and turfgrass establishment. The results of this study suggest that the optimum seed zone temperature for germination of Festuca cultivars is $15^{\circ} \mathrm{C}$. Germination decreased as average time to germination increased. The seeding time for some Festuca cultivars could be varied based on expected seed zone temperatures for particular locations. Results of this study should be interpreted with caution, but they suggest that selec- tion of cultivars based on anticipated seed zone temperatures will provide rapid germination and may lead to improved establishment on poorly managed sandy soils in cold climates.

\section{LITERATURE CITED}

Angus, J.F., R.B. Cunningham, M.W. Moncur, and D.H. Mackenzie (1981) Phasic development in field crops. I. Thermal response in the seedling phase. Field Crops Research, 3: 365-378.

AOSA (1970) Rules for testing seeds. In Proceedings of the Association of Official Seed Analysts, 60: 1116.

Bierhuizen, J.F., and W.A. Wagenvoort (1974) Some aspects of seed germination in vegetables. 1 . The determination and application of heat sums and minimum temperature for germination. Scientific Horticulture, 2: 213-219.

Brar, G.S., and A.J. Palazzo (1995a) Tall and hard fescue responses to periodic soil water deficits. Journal of Agronomy and Crop Science, 175: 221-229. Brar, G.S., and A.J. Palazzo (1995b) Shoot and root development of tall and hard fescues in two different soils. Journal of Environmental Quality, 24: 777-781.

Brar, G.S., and B.A. Stewart (1994) Germination under controlled temperature and field emergence of 13 sorghum cultivars. Crop Science, 34: 1336-1340.

Brar, G.S., J.F. Gomez, B.L. McMichael, A.G. Matches, and H.M. Taylor (1991) Germination of twenty forage legumes as influenced by temperature. Agronomy Journal, 83:173-175.

Derwyn, R., B. Whalley, and C.M. McKell (1966) Seedling vigour and the early non-photosynthetic stage of seedling growth in grasses. Crop Science, 6: $147-150$.

Doliner, L.H., and P.A. Jolliffe (1979) Ecological evidence concerning the adaptive significance of the C4 dicarboxylic acid pathway of photosynthesis. Oecologia, 38: 23-34.

Garcia-Huidobro, J., J.L. Monteith, and G.R. Squire (1982) Time, temperature and germination of pearl millet. Journal of Experimental Botany, 33: 288-296.

Gould, F.W., and R.B. Shaw (1983) Grass Systematics. Second edition, p. 397. College Station: Texas A\&M University Press.

Hegarty, T.W. (1973) Temperature coefficient (Q10), seed germination and other biological processes. Nature (London), 243: 305-306.

Heydecker, W. (1966) Clarity in recording germination data. Nature, (London), 210: 753-754. 
Hsu, F.H., C.J. Nelson, and A.G. Matches (1985) Temperature effects on germination of perennial warm-season forage grasses. Crop Science, 25: 215-220.

Kempthorne, O. (1952) The design and analysis of experiments. New York: John Wiley and Sons.

McWilliam, J.R., J.R. Clements, and P.M. Dowling (1970) Some factors influencing the germination and early seedling development of pasture plants. Australian Journal of Agricultural Research, 21: 1932.

Palazzo, A.J. (1994) Establishment and persistence of cool- and warm-season grasses on sandy soils. USA Cold Regions Research and Engineering Laboratory, Special Report 94-31.

Palazzo, A.J., and G.S. Brar (1997) Screening of 12 Festuca cultivars for rapid root development. Journal of Turfgrass Management, 2: 15-25.

Qi, M.Q., and R.E. Redmann (1993) Seed germination and seedling survival of $\mathrm{C} 3$ and $\mathrm{C} 4$ grasses under water stress. Journal of Arid Environments, 24: 277-285.

Radford, B.J., and R.G. Henzell (1990) Temperature affects the mesocotyle and coleoptile length of grain sorghum genotypes. Australian Journal of Agricultural Research, 41: 79-87.

Smith, D.F. (1968) The growth of barley grass (Hordeum leporinunum) in an annual pasture. I. Germination and establishment in comparison with other annual pasture species. Australian Journal of Experimental Agriculture and Animal Husbandry, 8: 478-483.

Thompson, P.A., and D.J.C. Fox (1976) The germination responses of vegetable seeds in relation to their history of cultivation by man. Scientific Horticulture, 4: 1-14.

Wheeler, T.R., and R.H. Ellis (1991) Seed quality, cotyledon elongation at suboptimal temperatures, and the yield of onion. Seed Science Research, 1: 57-67. 


\section{REPORT DOCUMENTATION PAGE}

Public reporting burden for this collection of information is estimated to average 1 hour per response, including the time for reviewing instructions, searching existing data sources, gathering and maintaining the data needed, and completing and reviewing the collection of information. Send comments regarding this burden estimate or any other aspect of this collection of information, including suggestion for reducing this burden, to Washington Headquarters Services, Directorate for Information Operations and Reports, 1215 Jefferson Davis Highway, Suite 1204, Arlington, VA 22202-4302, and to the Office of Management and Budget, Paperwork Reduction Project (0704-0188), Washington, DC 20503.

\begin{tabular}{|l|l|l}
\hline 1. AGENCY USE ONLY (Leave blank) & $\begin{array}{c}\text { 2. REPORT DATE } \\
\text { August } 1997\end{array}$ & 3. REPORT TYPE AND DATES COVERED \\
\hline
\end{tabular}

4. TITLE AND SUBTITLE

The Effects of Temperature on Germination of

Eleven Festuca Cultivars

6. AUTHORS

Antonio J. Palazzo and Gurdarshan S. Brar

7. PERFORMING ORGANIZATION NAME(S) AND ADDRESS(ES)

8. PERFORMING ORGANIZATION REPORT NUMBER

U.S. Army Cold Regions Research and Engineering Laboratory

72 Lyme Road

Special Report 97-19

Hanover, New Hampshire 03755-1290

9. SPONSORING/MONITORING AGENCY NAME(S) AND ADDRESS(ES)

10. SPONSORING/MONITORING AGENCY REPORT NUMBER

Office of the Chief of Engineers

Washington, D.C. 20314-1000

11. SUPPLEMENTARY NOTES For conversion of SI units to non-SI units of measurement consult Standard Practice for Use of the International System of Units (SI), ASTM Standard E380-93, published by the American Society for Testing and Materials, 1916 Race St., Philadelphia, Pa. 19103.1

12a. DISTRIBUTION/AVAILABILITY STATEMENT 12b. DISTRIBUTION CODE

Approved for public release; distribution is unlimited.

Available from NTIS, Springfield, Virginia 22161.

13. ABSTRACT (Maximum 200 words)

Many studies have shown that water potential at planting affects the germination rate and final germination of Festuca cultivars. Limited information is available about the extent of variability in temperature-dependence of germination among different Festuca cultivars. Our objective was to study germination at five temperatures for a wide range of Festuca cultivars. Festuca seeds were screened for germination during 28 days in polyethylene growth pouches held at constant temperatures of $10,15,20,25$, or $30^{\circ} \mathrm{C}$. The germination percentage significantly $(p<0.05)$ increased as the temperature increased from 10 to $15^{\circ} \mathrm{C}$, when averaged across the cultivars, and decreased thereafter. The cultivar "Clemfine" tall fescue (Festuca arundinacea Schreb.) had the greatest germination percentage, and "Arctared" red fescue (Festuca rubra L.) had the least when averaged across the five temperatures. Conversely, the average time to germination $\left(A_{\mathrm{tg}}\right)$ was greatest at $10^{\circ} \mathrm{C}$ and least at $30^{\circ} \mathrm{C}$. Reaching a germination level of $80 \%$ or more of the seeds required 14 days at $10^{\circ} \mathrm{C}, 9 \mathrm{~d}$ at $15^{\circ} \mathrm{C}, 8 \mathrm{~d}$ at $20^{\circ} \mathrm{C}$, and $7 \mathrm{~d}$ at 25 or $30^{\circ} \mathrm{C}$. Base temperatures required for germination of Festuca species were $3.2^{\circ} \mathrm{C}$ for rapid germinators, 3.6 to $6^{\circ} \mathrm{C}$ for medium germinators, and 4 to $6^{\circ} \mathrm{C}$ for poor germinators. Heat units (growing degree-days $>10^{\circ} \mathrm{C}$ ) calculated for the rapid germinators were $129^{\circ} \mathrm{C}-\mathrm{d}, 120$ to $140^{\circ} \mathrm{C}-\mathrm{d}$ for medium germinators, and 135 to $191^{\circ} \mathrm{C}$ - $\mathrm{d}$ for the poor germinators. Germination decreased as heat units were increased. The $A_{\mathrm{tg}}$ and heat unit regressions explained

\begin{tabular}{|c|c|c|c|c|}
\hline \multirow{2}{*}{$\begin{array}{l}\text { 14. SUBJECT TERMS } \\
\text { Festuca cultivars }\end{array}$} & \multirow[b]{2}{*}{ Germination } & \multirow[b]{2}{*}{ Temperature } & & \multirow{2}{*}{$\frac{15 \text { NUMBER OF PAGES }}{11}$} \\
\hline & & & & \\
\hline UNCLASSIFIED & $\mathrm{UNCl}$ & ASSIFIED & UNCLASSIFIED & UL \\
\hline
\end{tabular}


$91 \%$ and $66 \%$ of the variations in germination, respectively. The optimum temperature for germination of Festuca cultivars was $15^{\circ} \mathrm{C}$. Seeding time for some Festuca cultivars could be varied based on expected seed zone temperatures for particular locations. Results of this study should be interpreted with caution, but they suggest that selection for rapid growth rate among materials of favored phenological patterns may lead to improved establishment of faster species on poorly managed sandy soils in cold climates. Rapidity and total germination are the most obvious factors distinguishing Festuca cultivars. This study demonstrates the variability in cultivar germination in response to temperature. 